\title{
Antimicrobial Activity and Chemical Composition Screening of Anacyclus pyrethrum Root
}

\author{
Kerem Canli ${ }^{*}$, Ali Yetgin ${ }^{2}$, Ilgaz Akata ${ }^{3}$, Ergin Murat Altuner ${ }^{4}$ \\ ${ }^{1}$ Department of Biology, Faculty of Science, Dokuz Eylül University, Izmir, TURKEY \\ ${ }^{2}$ Department of Biotechnology, Institute of Engineering and Science, Izmir Institute of Technology, Izmir, TURKEY \\ ${ }^{3}$ Department of Biology, Faculty of Science, Ankara University, Ankara, TURKEY \\ ${ }^{4}$ Department of Biology, Faculty of Science and Arts, Kastamonu University, Kastamonu, TURKEY
}

\begin{abstract}
Medical herbs have many bioactive component and they are used in microbial treatment since ancient times. The resistance of pathogens to antibiotics became a critical problem, so researches for novel antimicrobial agents are required. Anacyclus pyrethrum (pellitory, Spanish chamomile or Mount Atlas daisy) is commonly used as a traditional medicine, therefore the antimicrobial activity of the root of this medicinal plant was investigated against 17 bacteria and 1 fungi by using disk diffusion method. The test strains include Bacillus, Enterobacter, Enterococcus, Escherichia, Klebsiella, Listeria, Pseudomonas, Salmonella, Staphylococcus and Candida genera. Besides, chemical composition of this sample was determined by Gas Chromatography-Mass Spectroscopy analysis. The results were presented that $A$. pyrethrum has antimicrobial activity against all tested microbial species except $E$. faecalis and $S$. typhimurium. Eighteen major chemical components were determined, but some composition of this sample is not match with library. For this reason, this medicinal plant contain unknown molecules and this molecules should be analysed NMR spectra for 3D structure determination and identification.
\end{abstract}

Keywords: Anacyclus pyrethrum, Medicinal Plant, Antimicrobial Activity, Chemical Composition, Disk Diffusion Method, Gc-Ms.

\section{INTRODUCTION}

Plants have been used as sources for many pharmaceuticals. ${ }^{1,2}$ Anacyclus pyrethrum (pellitory, Spanish chamomile or Mount Atlas daisy) root and leaf are important in traditional health and herbal medicine. In particular, $A$. pyretbrum root is known to have a good effect in traditional medical uses. ${ }^{3}$ This herbal plant has many uses in different cultures as aphrodisiac, analgesic, antirheumatic, antiarthritic, antibacterial, antiviral, antibiotic, anticatarrhal, carminative, digestion, diuretic, emmenagogue, febrifuge, nervine, vermifuge, sialagogue. ${ }^{4}$

Several experimental studies have been carried out on $A$. pyrethrum plant and many biological activities have been identified such as antibacterial, immunostimulating and antioxidant, antidepressant. ${ }^{5-11}$
The main objective of this scientific research is to determine the antimicrobial profile of A. pyrethrum and its ethanol extract's composition. The ethanol extract of this plant was prepared and tested against 17 bacteria and 1 fungi by disk diffusion method. In addition, GC-MS analysis was performed to identify the compounds in the ethanol extract of this plant, and the compounds were determined by comparison from Wiley Data Library.

\section{MATERIALS AND METHODS}

\section{Plant samples}

A. pyrethrum is a medicinal plant in Turkey and obtained from local market, 5.14, 10.29 and $20.57 \mathrm{mg}$ A. pyrethrum samples were prepared with ethanol extraction process. ${ }^{12}$
DOI: 10.5530/ijper.51.3s.22 Correspondence: Kerem Canli, Department of Biology, Faculty of Science, Dokuz Eylül University, Izmir, TURKEY

Phone no: +90 2323019543 E-mail: biyoloji@gmail.com 


\section{Antimicrobial activity test}

17 bacteria and 1 fungi were used and sustained on Nutrient Agar (BD Difco, USA). ${ }^{13}$ Microorganism inoculum process was applied as done in previous study. The antimicrobial activity of $A$. pyrethrum was performed by disk diffusion test. ${ }^{14}$

\section{Gas chromatography-mass spectrophotometry method (GC-MS)}

GC-MS has been used as a tool to identify the composition of medicinal plants for years. ${ }^{15}$ For the identification of chemical components, each sample was analysed by Shimadzu GCMS QP 2010 ULTRA equipped with RTX-5MS capillary column $(30 \mathrm{~m} * 0.25 \mathrm{~mm}$; coating thickness $0.25 \mu \mathrm{m}$ ). Analytical conditions were an injector temperature of $250{ }^{\circ} \mathrm{C}$; carrier gas Helium at $1.78 \mathrm{~mL} / \mathrm{min}$; injection mode: split, split ratio 10:1; volume injected: $1 \mu \mathrm{L}$ of sample in ethanol extract and oven temperature programmed from $40{ }^{\circ} \mathrm{C}$ to $290{ }^{\circ} \mathrm{C}$ at $4{ }^{\circ} \mathrm{C} / \mathrm{min}$, pressure: $100 \mathrm{kPa}$, total flow: $13.7 \mathrm{~mL} / \mathrm{min}$. The MS scan conditions were an interface temperature of $250^{\circ} \mathrm{C}$, and an ion source temperature of $200{ }^{\circ} \mathrm{C}$. GC-MS chromatogram for this analysis is given in Figure 1. Identification of these components were conducted by matching the retention times against Wiley Data Library and a crosscheck was applied with previously published data. ${ }^{16}$ The chemical components found to be higher than 1\% were accepted as the major components and the list and information regarding them are given in Table 2.

\section{Controls}

Empty sterile disks and extraction solvent (ethanol) were used as negative controls.

\section{Statistics}

The statistical analysis was executed using a parametric method, the one-way repeated measures ANOVA, with a significance level of $0.05 .{ }^{17}$ In order to put forward any correlation between concentration and antimicrobial activity Pearson correlation coefficient was calculated. ${ }^{18}$ All statistical analysis were conducted by using R Studio, version 3.3.2. ${ }^{19}$

\section{RESULTS AND DISCUSSIONS}

The diameter of these zones were measured as diameters in millimetres and given with standard errors in Table 1. No activities were observed for empty sterile disks and ethanol loaded disks, which are negative controls. Furthermore, statistical analysis proved that there are no significant difference between the activities of three parallels of each extract volumes, which are $30 \mu \mathrm{L}, 60 \mu \mathrm{L}$ and $120 \mu \mathrm{L}$, with $p$ values of $0.999,0.998$ and 0.998 respectively. On the other hand, the difference between the activities of three extract volumes are observed not to be statistically significant too with a $p$ value of 0.195 . In addition, a weak positive correlation was observed between increasing the extract volume tested and the activity observed, where the Pearson correlation coefficient is 0.2322 .

In Table 1, A. pyrethrum presented antimicrobial activity against all tested microbial strains except E. faecalis and $S$. typhimurium. Two of them have potent activity (> $30 \mathrm{~mm})$; five of them have strong activity $(21-30 \mathrm{~mm})$; five of them have moderate activity (16-20 mm), seven of them have weak activity $(10-15 \mathrm{~mm})$ and thirty five of them have little activity $(<10 \mathrm{~mm}){ }^{20}$

Jalayer Naderi et al. analysed antimicrobial activity of A. pyrethrum methanol extract against 4 bacteria. ${ }^{5}$ Inhibition zones only obtained for $S$. aureus $(27 \mathrm{~mm})$ and S. sanguis $(21 \mathrm{~mm})$ at $1000 \mathrm{mg} / \mathrm{mL}$. In our study, the activity against $S$. aureus was found $21 \mathrm{~mm}$ of inhibition zone for $20.57 \mathrm{mg}$ of extract. It is most probable that increasing the amount of the extract may cause higher activity against this bacteria. In addition, no activity against $S$. mutans and $P$. aeruginosa were determined in their studies. In our study, the activity against $P$. aeruginosa was observed $18 \mathrm{~mm}$ of inhibition zone for $20.57 \mathrm{mg}$ of extract.

Selles et al. analysed methanol, water and chloroform extracts of $A$. pyrethrum against 6 microorganisms. ${ }^{6}$ The methanol extract was found to have higher antimicrobial activity, but larger zones were obtained by the ethanol extract in our study.

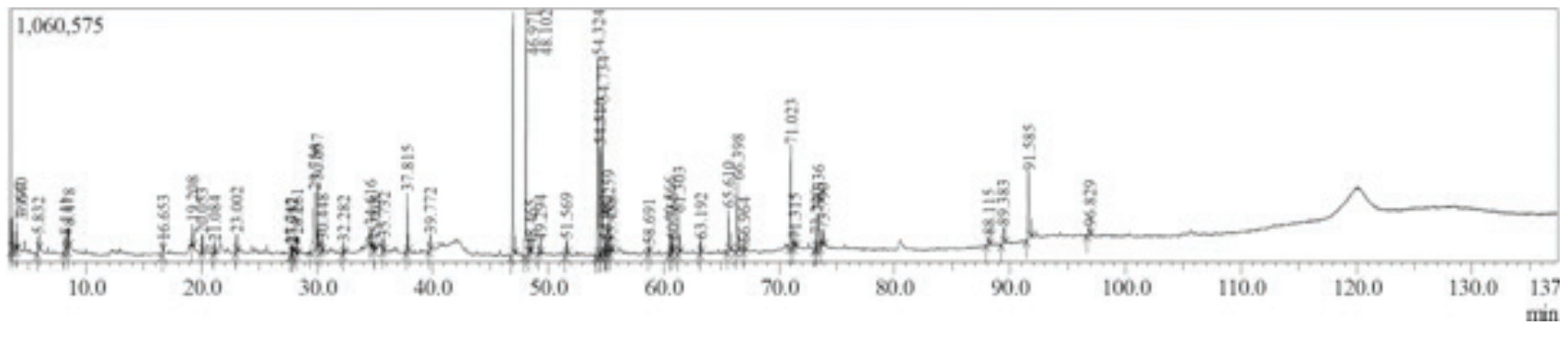

Figure 1: GC-MS chromatogram of $A$. pyrethrum. 


\begin{tabular}{|c|c|c|c|}
\hline \multicolumn{3}{|c|}{ Table 1: Disk diffusion test result for Anacyclus pyrethrum (Inhibition zones in mm). } \\
\hline Bacillus subtilis DSMZ 1971 & $\mathbf{3 0} \boldsymbol{\mu L}$ & $\mathbf{6 0} \boldsymbol{\mu L}$ & $\mathbf{1 2 0} \boldsymbol{\mu L}$ \\
\hline Candida albicans DSMZ 1386 & $9,00 \pm 0,00$ & $10,00 \pm 0,00$ & $12,00 \pm 0,00$ \\
\hline Enterobacter aerogenes ATCC 13048 & $7,00 \pm 0,00$ & $9,00 \pm 0,58$ & $12,00 \pm 0,00$ \\
\hline Enterecoccus faecalis ATCC 29212 & - & - & $9,00 \pm 0,00$ \\
\hline Enterecoccus faecium & - & - & - \\
\hline Enterococcus durans & $21,00 \pm 0,00$ & $26,00 \pm 0,00$ & $33,00 \pm 0,58$ \\
\hline Escherichia coli ATCC 25922 & $8,00 \pm 0,00$ & $10,00 \pm 0,58$ & $13,00 \pm 0,00$ \\
\hline Klebsiella pneumoniae & - & $7,00 \pm 0,00$ & $8,00 \pm 0,00$ \\
\hline Listeria innocua & - & - & $7,00 \pm 0,00$ \\
\hline Listeria monocytogenes ATCC 7644 & $8,00 \pm 0,00$ & $8,00 \pm 0,00$ & $8,00 \pm 0,00$ \\
\hline Pseudomonas aeruginosa DSMZ 50071 & $11,00 \pm 0,58$ & $14,00 \pm 0,00$ & $16,00 \pm 0,00$ \\
\hline Pseudomonas fluorescens P1 & $12,00 \pm 0,00$ & $16,00 \pm 0,00$ & $18,00 \pm 0,00$ \\
\hline Salmonella enteritidis ATCC 13076 & - & $8,00 \pm 0,00$ & $11,00 \pm 0,00$ \\
\hline Salmonella infantis & $8,00 \pm 0,00$ & $9,00 \pm 0,00$ & $10,00 \pm 0,58$ \\
\hline Salmonella kentucky & $7,00 \pm 0,00$ & $8,00 \pm 0,00$ & $9,00 \pm 0,00$ \\
\hline Salmonella typhimurium SL1344 & $7,00 \pm 0,00$ & $9,00 \pm 0,00$ & $10,00 \pm 0,00$ \\
\hline Staphylococcus aureus ATCC 25923 & $16,00 \pm 0,00$ & $19,00 \pm 0,00$ & $21,00 \pm 0,00$ \\
\hline Staphylococcus epidermidis DSMZ 20044 & $25,00 \pm 0,00$ & $28,00 \pm 0,00$ & $32,00 \pm 0,00$ \\
\hline
\end{tabular}

"-":No inhibition

\begin{tabular}{|c|c|c|c|c|c|}
\hline No & $\begin{array}{l}\text { Retention } \\
\text { Time }\end{array}$ & Compound name & Formula & $\begin{array}{c}\text { Molecular } \\
\text { Weight }(\mathrm{g} / \mathrm{mol})\end{array}$ & $\begin{array}{c}\text { Area } \\
(\%)\end{array}$ \\
\hline 1 & 29.756 & Benzofuran-2-carboxaldehyde & $\mathrm{C}_{9} \mathrm{H}_{6} \mathrm{O}_{2}$ & 146.143 & 5.50 \\
\hline 2 & 30.057 & Benzaldehyde, 2-hydroxy-6-methyl- & $\mathrm{C}_{8} \mathrm{H}_{8} \mathrm{O}_{2}$ & 136.148 & 2.68 \\
\hline 3 & 37.815 & Triisobutyl(3-phenylpropoxy)silane & $\mathrm{C}_{21} \mathrm{H}_{38} \mathrm{OSi}$ & 334.611 & 1.89 \\
\hline 4 & 46.971 & Naphthalene, decahydro-1,1-dimethyl- & $\mathrm{C}_{12} \mathrm{H}_{22}$ & 166.303 & 10.86 \\
\hline 5 & 48.102 & Palmitic acid & $\mathrm{C}_{16} \mathrm{H}_{32} \mathrm{O}_{2}$ & 256.424 & 13.39 \\
\hline 6 & 54.324 & 9,12-Octadecadienoic acid (Z,Z)- & $\mathrm{C}_{18} \mathrm{H}_{32} \mathrm{O}_{2}$ & 280.445 & 10.10 \\
\hline 7 & 54.510 & 7-Tetradecenal, (Z)- & $\mathrm{C}_{14} \mathrm{H}_{26} \mathrm{O}$ & 210.356 & 7.08 \\
\hline 8 & 54.734 & $\mathrm{~N}$-Isobutyl-tetradeca-2,4-dienamide & $\mathrm{C}_{18} \mathrm{H}_{33} \mathrm{NO}$ & 279.461 & 7.60 \\
\hline 9 & 55.259 & Octadecanoic acid & $\mathrm{C}_{18} \mathrm{H}_{36} \mathrm{O}_{2}$ & 284.477 & 1.99 \\
\hline 10 & 60.566 & N-Isobutyl-(2E,4Z,8Z,10E)-dodecatetraenamide & $\mathrm{C}_{16} \mathrm{H}_{25} \mathrm{NO}$ & 247.376 & 1.15 \\
\hline 11 & 61.303 & N-Isobutyl-tetradeca-2,4-dienamide & $\mathrm{C}_{18} \mathrm{H}_{33} \mathrm{NO}$ & 279.461 & 1.56 \\
\hline 12 & 65.610 & Hexadecanoic acid, 2-hydroxy-1-(hydroxymethyl)ethyl ester & $\mathrm{C}_{19} \mathrm{H}_{38} \mathrm{O}_{4}$ & 330.503 & 1.81 \\
\hline 13 & 66.398 & Unknown & - & - & 2.82 \\
\hline 14 & 71.023 & Octadecanoic acid, 2,3-dihydroxypropyl ester & $\mathrm{C}_{21} \mathrm{H}_{42} \mathrm{O}_{4}$ & 358.556 & 4.62 \\
\hline 15 & 73.336 & Unknown & - & - & 2.98 \\
\hline 16 & 73.790 & Squalene & $\mathrm{C}_{30} \mathrm{H}_{50}$ & 410.718 & 1.03 \\
\hline 17 & 89.383 & Stigmasterol & $\mathrm{C}_{29} \mathrm{H}_{48} \mathrm{O}$ & 412.691 & 1.29 \\
\hline 18 & 91.585 & gamma.-Sitosterol & $\mathrm{C}_{29} \mathrm{H}_{50} \mathrm{O}$ & 414.707 & 5.49 \\
\hline
\end{tabular}


The difference between our study and previous studies could depend on several reasons: (1) the microorganism strains used in these two studies may be different, (2) the location and collection season of $A$. pyrethrum may cause a change in active components, (3) the amount of extracts tested on microorganisms were different and (4) the type of extraction solvent may change the active compounds extracted from plant samples.

According to Table 2, Palmitic acid (13.39\%), Naphthalene, decahydro-1,1-dimethyl-(10.86\%), 9,12-Octadecadienoic acid (Z,Z)- (10.10\%), N-Isobutyl-tetradeca-2,4-dienamide (7.60\%), 7-Tetradecenal, (Z)- (7.08\%), Benzofuran2-carboxaldehyde (5.50\%) and. gamma.-Sitosterol (5.49\%) are mainly found in the composition of $A$. pyrethrum ethanol extract.

\section{CONCLUSION}

A. pyrethrum has antimicrobial activity against large range of microorganisms. It is possible to recommend that further researches are needed to determine the mechanism of actions and antibiotic interactions due to the active compounds' pharmacokinetic profiles.

\section{ACKNOWLEDGEMENT}

None

\section{CONFLICT OF INTEREST}

None

\section{ABBREVIATION USED}

GC-MS, gas chromatography-mass spectrophotometry method; NMR, nuclear magnetic resonance; 3D, three dimensional.

\section{REFERENCES}

1. Agarwal A, Prajapati R, Raza SK, Thakur LK. GC-MS Analysis and Antibacterial Activity of Aerial Parts of Quisqualis indica Plant Extracts. Indian J Pharm Educ. 2017;51:329-36.
2. Powar TA, Hajare AA, Patil-Vibhute PB, Nadaf SJ, Jarag RJ. Bioadhesive Garlic and Ketoconazole Vaginal Tablets for Treatment of Candidiasis. Indian J Pharm Educ. 2017;51:239-48.

3. Kumar VK, Lalitha KG. Pharmacognostical studies on the root of Anacyclus pyrethrum DC. Indian J Nat Prod Resour. 2012;3:518-26.

4. Usmani A, Khushtar M, Arif M, Siddiqui MA, Sing SP, Mujahid M. Pharmacognostic and phytopharmacology study of Anacyclus pyrethrum: An insight. J Appl Pharm Sci. 2016;6:144-50.

5. Jalayer Naderi N, Niakan M, Khodadadi E. Determination of antibacterial activity of Anacyclus pyrethrum extract against some of the oral bacteria: an in vitro study. J Dent Shiraz Univ Med Sci. 2012;13(2):59-63.

6. Selles C, Dib MEA, Allali H, Tabti B. Evaluation of antimicrobial and antioxidant activities of solvent extracts of Anacyclus pyrethrum L., from Algeria. Mediterr J Chem. 2012;2:408-15.

7. Bendjeddou D, Lalaoui K, Satta D. Immunostimulating activity of the hot water-soluble polysaccharide extracts of Anacyclus pyrethrum, Alpinia galanga and Citrullus colocynthis. J Ethnopharmacol. 2003;88(2):155-60.

8. Sujith K, Darwin CR, Suba V. Antioxidant activity of ethanolic root extract of Anacyclus pyrethrum. Int Res J Pharm. 2011;2(8):222-6.

9. Badhe SR, Badhe RV, Ghaisas MM, Chopade VV, Deshpande AD. Evaluations of antidepressant activity of Anacyclus pyrethrum root extract. Int J Green Pharm. 2010;4(2).

10. Bhargava NC, Singh OP. Fortege and indigenous drug in common sexual disorders in males. Mediscope. 1978;21:140-4.

11. Galani VJ, Patel BG, Patel NB. Argyreia speciosa (Linn. f.) sweet: A comprehensive review. Plant Review. 2010;4(8):172-8.

12. Canli K, Altuner EM, Akata I. Antimicrobial screening of Mnium stellare. Bangladesh J Pharmacol. 2015;10(2):321-5.

13. Canli K, Akata I, Altuner EM. In vitro antimicrobial activity screening of Xylaria hypoxylon. Afr J Tradit Complement Altern Med. 2016;13(4):42-6.

14. Canli K, Yetgin A, Akata I, Altuner EM. In vitro antimicrobial screening of Aquilaria agallocha roots. Afr J Tradit Complement Altern Med. 2016;13(5):178-81.

15. Bharat CR, Krishna GD. GC-MS Analysis of Young Leaves of Allophylus cobbe (L.) Raeusch and Allophylus serratus (Roxb.) Kurz. Indian J Pharm Educ. 2017;51:472-9.

16. Canli K, Altuner EM, Akata I, Turkmen Y, Uzek U. In vitro antimicrobial screening of Lycoperdon lividum and determination of the ethanol extract composition by gas chromatography/mass spectrometry. Bangladesh $\mathrm{J}$ Pharmacol. 2016;11(2):389-94.

17. Chambers JM, Hastie TJ. Statistical Models in S. Wadsworth \& Brooks/Cole; 1992.

18. Becker RA, Chambers JM, Wilks AR. The New S Language. Wadsworth \& Brooks/Cole; 1988.

19. Core $R$ Team. R: A language and environment for statistical computing. $R$ Foundation for Statistical Computing. Vienna (Austria): R-project; 2016.

20. Kim MJ, Lee SH, Cho JH, Kim MK, Lee HS. Growth responses of seven intestinal bacteria against Phellodendron amurense root-derived materials. J Microbiol Biotechnol. 2003;13(4):522-8.

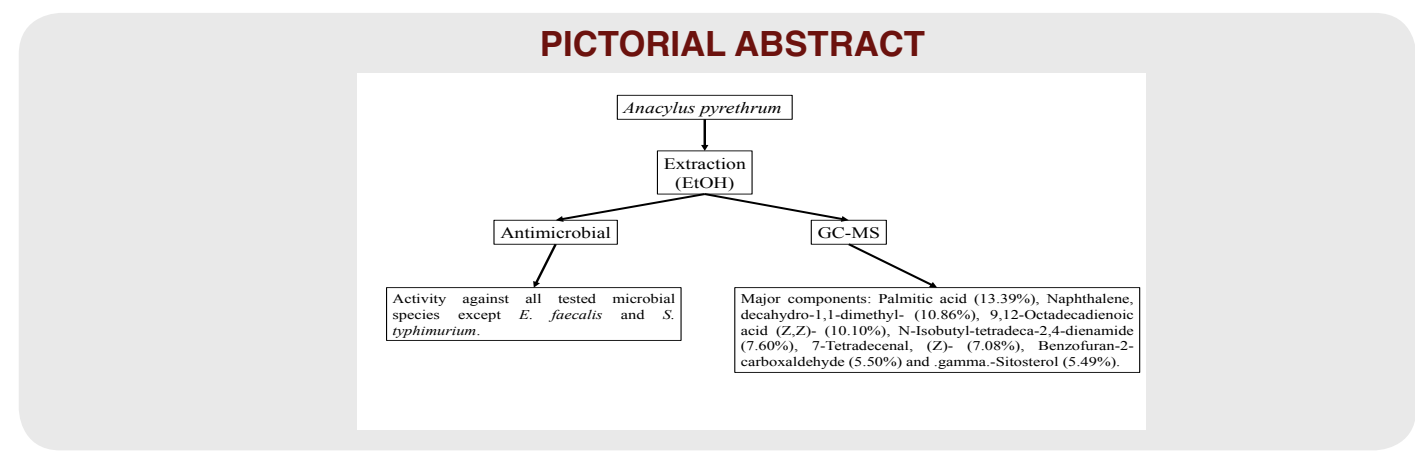




\section{SUMMARY}

- The antimicrobial activity of Anacyclus pyrethrum was analysed against 17 bacteria and 1 fungi by using disk diffusion method.

- The test microorganisms included Bacillus, Enterobacter, Enterococcus, Escherichia, Klebsiella, Listeria,Pseudomonas, Salmonella, Staphylococcus and Candida genera.

- The chemical composition of this sample was determined by Gas Chromatography-Mass Spectroscopy.

- The extract was observed to be active against all tested microbial species except E. faecalis and $S$. typhimurium.

- The major chemical components were observed as Palmitic acid (13.39\%), Naphthalene, decahydro1,1-dimethyl- (10.86\%), 9,12-Octadecadienoic acid (Z,Z)- (10.10\%), N-Isobutyl-tetradeca-2,4-dienamide

- (7.60\%), 7-Tetradecenal, (Z)- (7.08\%), Benzofuran-2- carboxaldehyde (5.50\%) and .gamma.-Sitosterol $(5.49 \%)$, but some components of this sample didn't match with the library.

\section{ABOUT AUTHORS}

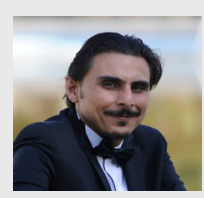

Kerem CANLI is working as an Assistant Professor in Dokuz Eylul University, Faculty of Science, Department of Biology, Izmir, TURKEY. He completed his B.Sc. and Ph.D. degree in Ankara University.

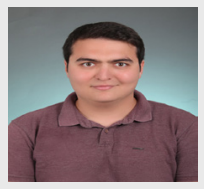

Ali YETGIN is completed his B.Sc. in Izmir Institute of Technology, Faculty of Science, Department of Molecular Biology, Izmir, TURKEY. He is now studying on his M.Sc. thesis.

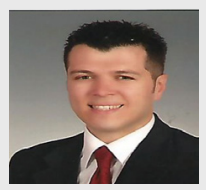

Ilgaz AKATA is working as an Associate Professor in Ankara University, Faculty of Science, Department of Biology, Ankara, TURKEY. He completed his B.Sc., M.Sc. and Ph.D. degree in Ankara University.

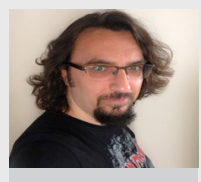

Ergin Murat Altuner is working as an Associate Professor in Kastamonu University, Faculty of Science and Arts, Department of Biology, Kastamonu, TURKEY. He completed his B.Sc. degree in Ankara University, M.Sc. degree in Middle East Technical University and Ph.D. degree in Ankara University.

Cite this article: Canli K, Yetgin A, Akata I, Altuner EM. Antimicrobial Activity and Chemical Composition Screening of Anacyclus Pyrethrum Root. Indian J of Pharmaceutical Education and Research. 2017;51(3)Suppl:S244-48. 